\title{
IMPLEMENTASI PEMENUHAN HAK MENDAPATKAN MAKANAN YANG LAYAK BAGI NARAPIDANA \\ DI LEMBAGA PEMASYARAKATAN KLAS 1 MAKASSAR
}

\author{
Oleh: \\ MANAN SAILAN \\ IRFANA LUTIA ILYAS \\ Dosen Jurusan PPKn FIS Universitas Negeri Makassar
}

\begin{abstract}
ABSTRAK: Penelitian ini bertujuan untuk mengetahui implementasi pemenuhan hak mendapatkan makanan yang layak bagi narapidana di lembaga pemasyarakatan klas I Makassar, kendala apa yang dihadapi pihak lembaga pemasyarakatan dalam implementasi pemenuhan hak mendapatkan makanan yang layak bagi narapidana di Lembaga Pemasyarakatan Klas I Makassar. Untuk mencapai tujuan tersebut maka teknik pengumpulan data melalui observasi, wawancara, dan dokumentasi. Data yang diperoleh dari hasil penelitian yang diolah menggunakan analisis deskriptif kualitatif untuk mengetahui implementasi pemenuhan hak mendapatkan makanan yang layak di lembaga pemasyarakatan klas I Makassar. Hasil penelitian menunjukkan bahwa : 1. Implementasi pemenuhan hak mendapatkan makanan yang layak bagi warga binaan pemasyarakatan di lembaga pemasyaraktan kelas 1 Makassar belum layak. Warga binaan pemasyarakatan banyak mengeluhkan makanan yang mereka konsumsi kurang enak dengan berbagai alasan diantaranya kebersihan makanan yang kurang diperhatikan, penyedap rasa yang kurang serta gizi makanan yang kurang seimbang. Kemudian dalam proses pelaksanaan pemenuhan hak mendapatkan makanan yang layak bagi narapidana ada beberapa hal yang tidak sesuai dengan prosedur dari Surat Keputusan Menteri Hukum dan HAM Nomor M.HH-01.PK.07.02 Tahun 2009 tentang Pedoman Penyelenggaraan Makanan Bagi Warga Binaan Pemasyarakatan di Lembaga Pemasyarakatan dan Rumah Tahanan Negara (Rutan). Sehingga implementasi pemenuhan hak mendapatkan makanan yang layak bagi narapidana berdasarkan Undang-Undang Nomor 12 Tahun 1995 tentang Pemasyarakatan belum terlaksana dengan baik. 2 . Kendala yang dihadapi tidak terlaksana dengan baiknya pemenuhan hak mendapatkan makanan yang layak bagi narapidana Lembaga Pemasyarakatan Klas 1 Makassar diantaranya anggaran yang rendah sehingga berdampak pada fasilitas sarana dan prasarana yang kurang memadai. Tidak tersedianya juru masak ahli di Lembaga Pemasyarakatan dan ahli gizi yang dapat menilai langsung makanan yang disajikan sudah bergizi atau belum, sehingga berdampak pada kualitas makanan yang buruk dan gizi makanan yang tidak seimbang. Kemudian daya tampung lembaga pemasyarakatan yang tidak seimbang dengan jumlah warga binaan pemasyarakatan yang terus bertambah (over kapasitas) yang mengakibatkan pelaksanaan pemenuhan hak mendapatkan makanan yang layak belum maksimal.
\end{abstract}

KATA KUNCI: Hak Asasi Manusia, Hak-Hak Narapidana, Makanan.

ABSTRACT: This study aims to determine the fulfillment of the implementation of the right to get a decent meal for inmates in prisons Class I Makassar, obstacles faced in the implementation of the correctional institution fulfilling the right to get a decent meal for inmates at the Correctional Institution Class I Makassar. To achieve these objectives, the technique of collecting data through observation, interviews, and documentation. Data obtained from the research that was processed using descriptive and qualitative analysis to determine compliance with the implementation of the right to adequate food in prisons 
Class I Makassar. The results showed that: 1. Implementation of the fulfillment of the right to adequate food for prisoners in institutions pemasyaraktan class 1 Makassar has not been feasible. Prisoners often complain the food they consume less palatable to various reasons including less attention to food hygiene, flavors that are less and less balanced nutritional meal. Later in the implementation process of the fulfillment of the right to get a decent meal for inmates there are some things that are not in accordance with the procedures of the Decree of the Minister of Law and Human Rights No. M.HH01.PK.07.02 Year 2009 on Guidelines for the Implementation of Food for People in Prison Correctional Patronage and the State Prison (Rutan). So that the implementation of the fulfillment of the right to get a decent meal for inmates under Act No. 12 of 1995 concerning Corrections has not done well. 2. Constraints faced by not performing well fulfillment of the right to get a decent meal for inmates Penitentiary Class 1 Makassar such a low budget so the impact on infrastructure facilities and inadequate infrastructure. Unavailability cook expert in Penitentiary and nutritionists to assess directly the served meals nutritious or not, so the impact on the poor quality of food and nutrition unbalanced diet. Then the capacity of prisons is not balanced by the number of prisoners is increasing (over capacity), which resulted in the implementation of the fulfillment of the right to get a decent meal is not maximized.

\section{Keywords: Human Rights, Rights of Prisoners, Food.}

\section{PENDAHULUAN}

Dalam pemerintahan suatu Negara pasti diatur mengenai hukum dan pemberian sanksi atas pelanggaran hukum tersebut. Hukum merupakan keseluruhan kumpulan peraturan-peraturan atau kaedah dalam suatu kehidupan bersama yang dapat di paksakan pelaksanaannya dengan suatu sanksi. Hal ini berarti setiap individu harus mentaati peraturanperaturan yang telah ditetapkan pemerintah di dalam berlangsungnya kehidupan bermasyarakat dan bernegara.

Undang-Undang Dasar Negara Republik Indonesia menegaskan bahwa Negara Republik Indonesia adalah Negara yang berdasar atas hukum. Sebagai Negara hukum maka Indonesia harus selalu menjunjung tinggi hak asasi manusia. Selalu menjamin segala warga Negara bersamaan kedudukannya di dalam hukum dan pemerintahan serta wajib menjunjung hukum dan pemerintahan dengan tidak ada kecualinya.

Di dalam sistem pemidanaan Indonesia yang berdasarkan pancasila, pemikiran mengenai fungsi pemidanaan tidak lagi hanya sekadar penjeraan bagi narapidana, melainkan merupakan suatu rehabilitasi dan reintegrasi sosial bagi warga binaan pemasyarakatan yang dilaksanakan secara terpadu antara pembina, yang dibina dan masyarakat. Dalam menjalani pidananya, hak dan kewajiban tersangka telah diatur dalam sistem pemasyarakatan yaitu sistem pemidanaan yang menggantikan sistem kepenjaraan.

Dalam Undang-Undang Nomor 12 Tahun 1995 tentang Pemasyarakatan salah satu hak warga binaan pemasyarakatan yang diatur di dalamnya adalah hak untuk mendapatkan makanan yang layak. Makanan diperlukan untuk kehidupan karena makanan merupakan salah satu kebutuhan pokok bagi kehidupan manusia. Makanan berfungsi untuk memelihara proses tubuh dalam pertumbuhan atau perkembangan serta mengganti jaringan tubuh yang rusak, memperoleh energi untuk melakukan aktivitas sehari-hari, mengatur metabolisme dan berbagai keseimbangan air, mineral, dan cairan tubuh yang lain, juga berperan di dalam mekanisme pertahanan tubuh terhadap berbagai 
penyakit. Sampai dengan saat ini standar pemberian makanan bagi narapidana dan tahanan masih mengacu pada Surat Edaran Menteri Kehakiman RI No.M.02.UM.01.06 tahun 1989 tentang petunjuk pelaksanaan biaya bahan makanan bagi Narapidana/Tahanan Negara /Anak tentang peningkatan pelayanan makan bagi narapidana dan tahanan WBP Golongan Usia Energi (Kalori) 1 Pria dan Wanita Dewasa 2.250. Dalam rangka meningkatkan status gizi yang baik perlu di pertimbangkan kandungan kalori dan nilai gizi dari masing-masing bahan makanan yang akan di konsumsi oleh warga binaan pemasyarakatan dan tahanan sehingga kebutuhan makanan sedapat mungkin sesuai dengan standar kesehatan dan angka kecukupan gizi. Pidana penjara merupakan pidana yang paling sering di jatuhkan oleh putusan hakim, sehingga kondisi warga binaan pemasyarakatan patut untuk mendapatkan perhatian lebih.

Pelayanan makanan merupakan salah satu hak Warga Binaan Pemasyarakatan dan tahanan yang harus di penuhi oleh penyelenggara Lapas/Rutan. Hal ini guna mendukung pelaksanaan tugas pokok dan fungsi di bidang pembinaan, pelayanan dan keamanan yang tercantum dalam pasal 14 Undang-undang nomor 12 tahun 1995 tentang Pemasyarakatan. Makanan dengan kaidah gizi seimbang di butuhkan oleh warga binaan pemasyarakatan dan tahanan di Lapas/Rutan, untuk mempertahankan dan meningkatkan derajat kesehatan agar tidak sakit dan dapat melakukan aktivitasnya sehari-hari.

Pemberian makanan yang tidak cukup jumlah dan kualitasnya dapat menimbulkan berbagai gangguan kesehatan, diantaranya dapat menyebabkan kekurangan gizi sehingga mudah terserang penyakit, kurang motivasi dan apatis. Kondisi ini dapat berakibat pada meningkatnya beban Lapas/Rutan dalam upaya meningkatkan kesejahteraan warga binaan pemasyarakatan dan tahanan. Komitmen dan semangat kerja dari semua pihak yang terkait dengan kegiatan penyelenggaraan makanan di Lapas/Rutan dalam melaksanakan tugas dan fungsinya, akan mendukung terselenggaranya pemberian makanan dengan baik dan terjaga kuantitas maupun kualitasnya sesuai ketentuan yang berlaku.

Upaya peningkatan status kesehatan dan gizi masyarakat dalam rangka mewujudkan sumber daya manusia Indonesia yang mandiri untuk hidup sehat di arahkan untuk mencapai suatu kondisi di mana masyarakat Indonesia termasuk yang berada di institusi lembaga pemasyarakatan (Lapas) dan rumah tahanan Negara (Rutan) menyadari, mau dan mampu untuk mengenali, mencegah dan mengatasi permasalahan kesehatan yang dihadapi, sehingga dapat bebas dari gangguan kesehatan, baik yang disebabkan karena penyakit termasuk gangguan kesehatan akibat bencana maupun lingkungan dan perilaku yang tidak mendukung untuk hidup sehat.

Makanan dan minuman termasuk kebutuhan dasar terpenting dalam kehidupan manusia karena merupakan sumber energi satu-satunya. Sehingga apapun yang akan disajikan sebagai makanan maupun minuman haruslah memenuhi standar syarat utama, yaitu cita rasa makanan dan keamanan makanan dalam arti makanan tidak mengandung zat atau mikroorganisme yang dapat mengganggu kesehatan tubuh yang memakan.

Makanan dan minuman adalah kebutuhan pokok manusia yang diperlukan setiap saat dan harus ditangani dan di kelola dengan baik dan benar agar bermanfaat bagi tubuh. Pengelolaan yang baik dan benar pada dasarnya adalah mengelola makanan dan minuman berdasarkan kaidah-kaidah dari prinsip hygieni dan sanitasi makanan. Hygieni dan sanitasi makanan dan minuman adalah upaya mengendalikan faktor makanan, orang, tempat dan atau perlengkapannya. 
Makanan yang dikonsumsi di Lembaga Pemasyarakatan Klas 1 Makassar kebersihannya kurang dijaga dengan baik.

Narapidana sebagai warga binaan Lembaga Pemasyarakatan, sewaktu menjalani pidana di Lembaga Pemasyarakatan kurang diperhatikan hak asasi sebagai manusia. Perlu di pahami bahwa dengan pidana yang di jalani narapidana itu bukan berarti hak-haknya di cabut, mereka tetaplah manusia yang mempunyai hak-hak asasi tertentu yang terus melekat padanya selagi ia masih hidup.

Di dalam Lembaga Pemasyarakatan narapidana harus di berikan makanan dengan kualitas memenuhi syarat kesehatan. Makanan yang memenuhi syarat kesehatan atau makanan yang sehat adalah makanan yang higenis, bergizi, dan berkecukupan. Makanan yang higenis adalah makanan yang tidak mengandung kuman penyakit atau zat yang dapat membahayakan kesehatan. Makanan yang bergizi adalah makanan yang mengandung cukup karbohidrat, protein, lemak, mineral, vitamin, dan jumlah yang seimbang sesuai dengan kebutuhan. Makanan yang berkecukupan adalah makanan yang dapat memenuhi kebutuhan tubuh pada usia dan kondisi tertentu. Makanan yang tidak memenuhi syarat kesehatan merupakan makanan yang tidak memiliki fungsi yang baik untuk tubuh dan dapat merusak tubuh secara perlahan-lahan. Untuk mendapatakan makanan yang memenuhi syarat kesehatan maka perlu diadakan penanganan terhadap hygeni dan sanitasi makanan dan minuman.

Sehingga berdasarkan pemikiran tersebut menjadikan inspirasi bagi penulis untuk melakukan penelitian tentang "Implementasi pemenuhan hak mendapatkan makanan yang layak bagi narapidana di Lembaga Pemasyarakatan klas 1 Makassar".

\section{TINJAUAN PUSTAKA}

\section{A. Hakikat Implementasi}

Secara umum istilah implementasi dalam Kamus Besar Bahasa Indonesia berarti pelaksaan atau penerapan. Istilah implementasi biasanya dikaitkan dengan suatu kegiatan yang dilaksanakan untuk mencapai tujuan tertentu. Webster, merumuskan bahwa to implement mengimplementasikan berarti menyediakan sarana untuk melaksanakan sesuatu, menimbulkan dampak atau akibat terhadap sesuatu. Pengertian tersebut mempunyai arti bahwa untuk mengimplementasikan sesuatu harus disertakan sarana yang mendukung yang nantinya akan menimbulkan dampak atau akibat terhadap sesuatu itu.

Pengertian Implementasi yang dikemukakan oleh Budi Winarto bahwa implementasi kebijakan dibatasi sebagai menjangkau tindakan-tindakan yang dilakukan oleh individu-individu pemerintah dan individu-individu swasta (kelompok-kelompok) yang diarahkan untuk mencapai tujuan-tujuan yang telah ditetapkan dalam keputusan-keputusan kebijaksanaan sebelumnya. Suatu proses implementasi kebijaksanaan itu sesungguhnya tidak hanya menyangkut perilaku badan-badan administratif yang bertanggung jawab melaksanakan suatu program yang telah ditetapkan serta menimbulkan ketaatan pada diri kelompok sasaran, melainkan pula menyangkut jaringan kekuatan-kekuatan politik, ekonomi, dan sosial yang secara langsung maupun tidak langsung dapat mempengaruhi segala pihak yang terlibat, sekalipun dalam hal ini dampak yang diharapkan ataupun yang tidak diharapkan.

\section{B. Konsep Hak Asasi Manusia}

Manusia Sebagai makhluk ciptaan Tuhan Yang Maha Esa yang mengembang tugas mengelola dan memelihara alam semesta dengan penuh kekuasaan dan penuh tanggungjawab untuk 
kesejahteraan umat manusia, oleh pencipta-Nya di anugerahi hak asasi untuk menjamin kemuliaan dirinya serta keharmonisan lingkungannya.

Hak Asasi Manusia adalah hak dasar yang secara kodrati melekat pada diri manusia sejak dalam kandungan bersifat universal dan langgeng. Oleh karena itu harus dilindungi, dihormati, dipertahankan, dan tidak boleh diabaikan, dikurangi atau dirampas oleh siapapun.

Sudah melekat pada pengertian hak-hak manusia itu sendiri, bahwa hakhak asasi manusia harus dipahami dan dimengerti secara universal. Memerangi atau menentang universalitas hak-hak manusia berarti memerangi dan menentang hak-hak manusia.

Undang-Undang No. 39 Tahun 1999 tentang Hak Asasi Manusia merumuskan pengertian Hak Asasi Manusia adalah seperangkat hak yang melekat pada hakikat dan keberadaan manusia sebagai makhluk Tuhan Yang Maha Esa dan merupakan anugerahnya yang wajib dihormati, dijunjung tinggi dan dilindungi oleh Negara, hukum pemerintah dan setiap orang demi kehormatan serta perlindungan harkat dan martabat manusia. (Pasal I angka I Undang-Undang No. 39 Tahun 1999). Hak Asasi Manusia merupakan hak esensial yang dimiliki oleh setiap manusia dan harus dilindungi sebagaimana yang tertuang dalam makna charta atau Deklarasi Universal Hak Asasi Manusia. Dalam perjalanan sejarah untuk mencegah terus berlangsungnya pelanggaranpelanggaran Hak Asasi Manusia, PBB menetapkan sejumlah konvenan yang berkaistan dengan HAM seperti :
a. Konvenan Hak Sipil dan Politik
b. Konvenan Hak Ekonomi, Sosial dan Budaya
c. Konvenan Hak Anak
d. Konvensi menentang penyiksaan dan perlakuan atau penghukuman lain yang kejam, tidak manusiawi, atau

merendahkan martabat manusia

e. Standar minimun terhadap narapidanan maupun tahanan

f. Konvensi internasional penghapusan semua bentuk diskriminasi terhadap perempuan dan lain sebagainya.

Hak Asasi Manusia melekat pada diri manusia tanpa memandang bulu, termasuk juga narapidana dan tahanan. Standar perlakuan minimum bagi narapidana dan tahanan menyatakan bahwa hak yang hilang daripada narapidana dan tahanan hanyalah hak atas kebebasan. Akan tetapi hak-hak pada dirinya harus tetap diberikan selama mereka menjalani masa pidana atau masa tahanannya.

\section{Lembaga Pemasyarakatan}

Menurut Undang-undang Nomor 12 Tahun 1995 tentang Pemasyarakatan pada pasal 1 butir 3 adalah Lembaga pemasyarakatan yang selanjutnya disebut LAPAS adalah tempat untuk melaksanakan pembinaan Narapidana dan Anak Didik Pemasyarakatan.

Selama di LAPAS, warga binaan pemasyarakatan tetap memperoleh hakhaknya yang lain seperti layaknya manusia lainnya, dengan kata lain hak perdatanya tetap dilindungi seperti hak memperoleh perawatan kesehatan, makan, minum, pakaian, tempat tidur, latihan, keterampilan, olah raga atau rekreasi. Yang dimaksud warga binaan pemasyarakatan adalah narapidana, Anak Didik Pemasyarakatan dan Klien Pemasyarakatan.

\section{Sistem Pemasyarakatan}

Sistem pemasyarakatan merupakan suatu rangkaian kesatuan penegakan hukum pidana, oleh karena itu pelaksanaannya tidak dapat dipisahkan dari pengembangan konsepsi umum mengenai pemidanaan. Dalam UU No. 12 Tahun 1995 tentang Pemasyarakatanm 
pada pasal 1 ayat (2) menjelaskan tentang sistem pemasyarakatan. Sistem pemasyarakatan adalah suatu tatanan mengenai arah dan batas serta cara pembinaan wargaa binaan pemasyarakatan berdasarkan Pancasila yang dilaksanakan secara terpadu antara pembina, yang dibina, dan masyarakat untuk meningkatkan kualitas warga binaan pemasyarakatan agar menyadari kesalahan, memperbaiki diri, dan tidak mengulangi tindak pidana sehingga dapat diterima kembali oleh lingkungan masyarakat, dapat aktif berperan dalam pembangunan, dan dapat hidup secara wajar sebagai warga yang baik dan bertanggung jawab.

\section{E. Hak-hak Narapidana}

Hak-hak narapidana selama menjalani sebagai warga binaan pemasyarakatan sebagai berikut :

1) Melakukan ibadah sesuai dengan agama atau kepercayaannya

2) Mendapatkan perawatan, baik perawayan rohani maupun jasmani

3) Mendapatkan pendidikan dan pengajaran

4) Mendapatkan pelayanan kesehatan dan makanan yang layak

5) Menyampaikan keluhan

6) Mendapatkan bahan bacaan dan mengikuti siaran media massa lainnya yang tidak dilarang

7) Mendapatkan upah atau premi atas pekerjaan yang dilakukan

8) Menerima kunjungan keluarga, penasehat hukum atau orang tertentu lainnya

9) Mendapatkan pengurangan masa pidana

10) Mendapatkan kesempatan berasimilasi termasuk cuti mengunjungi keluarga

11) Mendapatkan pembebasan bersyarat

12) Mendapatkan cuti menjelang bebas
13) Mendapatkan hak-hak narapidana sesuai dengan peraturan perundang-undangan yang berlaku

\section{F. Makanan}

Secara umum pembangunan yang dilaksanakan di Indonesia adalah untuk mewujudkan manusia dan masyarakat Indonesia yang maju dan mandiri. Upaya peningkatan status kesehatan dan gizi masyarakat dalam rangka mewujudkan sumber daya manusia yang mandiri untuk hidup sehat diarahkan untuk mencapai suatu kondisi di mana masyarakat Indonesia termasuk yang berada di LAPAS dan Rumah Tahanan (Rutan) menyadari dan mampu untuk mengenali, mencegah dan mengatasi permasalahan kesehatan yang dihadapi, sehingga dapat bebas dari gangguan kesehatan, baik disebabkan karena penyakit termasuk gangguan kesehatan akibat bencana maupun lingkungan dan perilaku yang tidak mendukung hidup sehat. Mengenai konsep pelayanan makanan yang layak adalah :

1. Penetapan menu makanan bagi tiap-tiap narapidana dalam satu hari ditetapkan oleh menteri kehakiman.

2. Jumlah kalori makanan diatur sesuai dengan ketentuan yang berlaku dan memenuhi syarat kesehatan.

3. Besarnya kalori tidak boleh berkurang
a. 2.500 kalori perhari bagi orang dewasa
b. Tambahan 300 kalori perhari bagi wanita yang sedang hamil
c. Tambahan 800-1000 kalori perhari bagi bagi wanita yang sedang menyusui

4. Menu makanan bagi narapidana yang sedang sakit ditetapkan oleh dokter lembaga pemasyarakatan.

5. Tanpa saran atau nasehat dokter Lembaga

Pemasyarakatan, perubahan menu makanan bagi 
narapidana yang sakit tidak diperbolehkan.

\section{METODE PENELITIAN}

Penelitian ini adalah penelitian deskriptif kualitatif sebab penelitian deskriptif kualitatif ini menekankan pada pembangunan naratif atau deskripsi tekstual atas fenomena yang diteliti yang bertujuan untuk mendapatkan pemahaman tentang kenyataan melalui proses berpikir induktif.

Dalam penelitian ini sumber data primer yang menjadi informannya adalah Warga Binaan Pemasyarakatan.

Prosedur pengumpulan data yang digunakan dalam penelitian ini dalah wawancara, dokumentasi dan observasi. Wawancara adalah suatu percakapan yang diarahkan pada suatu masalah tertentu dan merupakan proses tanya jawab lisan dimana sua orang atau lebih berhadapan secara fisik. Dengan menggunakan teknik wawancara terpimpin, yang dilakukan oleh pewawancara dengan membawa sederetan pertanyaan atau pernyataan lengkap dan terperinci serta runtut. Yang menjadi informan dalam hal ini adalah Warga Binaan Pemasyarakatan dan Pegawai Lembaga Pemasyarakatan. Dokumentasi diartikan sebagai upaya untuk memperoleh data dan informasi berupa catatan tertulis/gambar yang tersimpan berkaitan dengan masalah yang diteliti. Dokumen merupakan fakta dan data tersimpan dalam berbagai bahan yang berbentuk dokumentasi. Observasi diperoleh dengan cara melakukan observasi pada ruang (tempat), pelaku, objek, perbuatan dan waktu untuk mengevaluasi atau melakukan pengukuran terhadap aspek yang menjadi objek penelitian.

Penelitian ini bersifat deskriptif analisis yang merupakan proses penggambaran lokasi penelitian sehingga dalam penelitian ini akan diketahui implementasi pemenuhan hak mendapatkan makanan yang layak bagi narapidana di lembaga pemasyarakatan klas 1 Makassar.

\section{PEMBAHASAN}

\section{Implementasi Pemenuhan Hak Mendapatkan Makanan Yang Layak Bagi Narapidana di Lembaga Pemasyarakatan Klas 1 Makassar.}

Upaya peningkatan status kesehatan dan gizi masyarakat dalam rangka mewujudkan sumber daya manusia Indonesia yang mandiri untuk hidup sehat diarahkan untuk mencapai suatu kondisi di mana masyarakat Indonesia termasuk yang berada di institusi lembaga pemasyarakatan (Lapas) dan rumah tahanan negara (Rutan) menyadari, mau dan mampu untuk mengenali, mencegah dan mengatasi permasalahan kesehatan yang dihadapi, sehingga dapat bebas dari gangguan kesehatan, baik yang disebabkan karena penyakit termasuk gangguan kesehatan akibat bencana maupun lingkungan dan perilaku yang tidak mendukung untuk hidup sehat.

Dalam Undang-Undang Nomor 12 Tahun 1995 tentang Pemasyarakatan dijelaskan bahwa petugas harus menyediakan makan dan minum. Penyediaan ini harus memperhatikan kandungan makanan, kebersihan, dan kesehatannya. Setiap narapidana dan tahanan harus disediakan makanan yang memiliki kandungan nutrisi yang sesuai dengan kesehatan oleh pihak administrasi, berkualitas, disiapkan dan disajikan secara benar pada jam-jam makan yang biasa. Selain itu air minum harus tersedia kapan pun narapidana membutuhkan.

Status gizi warga binaan pemasyarakatan sangat dipengaruhi oleh kualitas dan jumlah zat gizi yang dikonsumsi serta ada tidaknya penyakit. Faktor-faktor yang mempengaruhi status gizi warga binaan pemasyarakatan tersebut sangat terkait dengan tingkat ketersediaan pangan. Perlindungan terhadap setiap warga negara termasuk 
yang berada di lembaga pemasyarakatan atau Warga Binaan Pemasyarakatan merupakan Hak Asasi Manusia (HAM). Oleh karena itu, dengan meningkatkan kualitas dan jumlah zat gizi yang dikonsumsi sangat berperan dalam meningkatkan status gizi masyarakat, termasuk Warga Binaan Pemasyarakatan di lembaga pemasyarakatan.

Narapidana perlu dilindungi dari makanan dan minuman yang tidak memenuhi persyaratan kesehatan agar tidak membahayakan kesehatannya. Makanan dan minuman untuk warga binaan pemasyarakatan harus memenuhi standar kesehatan untuk itu perlu diadakan pengawasan yang baik untuk penyediaan makan bagi warga binaan pemasyarakatan. Makanan merupakan kebutuhan pokok manusia yang dibutuhkan setiap saat dan di manapun ia berada serta memerlukan pengelolaan yang baik dan benar agar bermanfaat bagi tubuh. Tanpa andanya makanan dan minuman manusia tidak dapat melangsungkan hidupnya.

Bahan makanan yang baik terkadang sulit untuk kita temui, karena jaringan pelayanan makanan yang begitu panjang dan melalui jaringan perdagangan yang begitu luas. Salah satu upaya mendapatkan makanan yang baiik adalah menghindari penggunaan bahan makanan yang berasal dari sumber yang tidak jelas karena tidak dapat dipertanggungjawabkan secara kualitasnya. Untuk itu bahan makanan yang masuk di lembaga pemasyarakatan harus benar-benar diperiksa dengan baik jangan sampai ada bahan makanan yang rusak sebab kandungan gizinya sudah berkurang serta tidak baik untuk kesehatan warga binaan. Di lembaga pemasyarakatan dilakukan lelang setiap setahun sekali untuk menentukan pemborong yang akan mendistribusikan makanan setiap harinya di lembaga pemasyarakatan.

Pelayanan makanan merupakan salah satu hak narapidana/tahanan yang harus dipenuhi oleh pihak lembaga pemasyarakatan. Hal ini ditujukan untuk mendukung pelaksanaan tugas pokok dan fungsi di bidang pembinaan, pelayanan, dan keamanan sebagaimana tercantum dalam pasal 14 Undang-Undang Nomor 12 Tahun 1995 tentang Pemasyarakatan. Berdasarkan peraturan Menteri Hukum dan Hak Asasi Manusia Republik Indonesia No. M.HH-01.PK.07.02 Tahun 2009 Tentang Pedoman Penyelenggaraan Makanan Bagi Warga Binaan Pemasyarakatan di Lembaga Pemasyarakatan dan Rumah Tahanan Negara yang selanjutnya disebut Rutan mengatur bahwa penyelenggaraan makanan di LAPAS dan Rutan dilaksanakan mulai dari proses perencanaan anggaran, perencanaan menu, perhitungan kebutuhan bahan makanan, pendistribusian makanan, pencatatan dan pelaporan, monitoring dan evaluasi.

\section{Kendala yang di Hadapi Pihak Lembaga Pemasyarakatan Dalam Pemenuhan Hak Mendapatkan Makanan yang Layak Bagi Narapidana}

Di dalam melaksanakan suatu tugas atau aktifitas petugas seringkali menghadapi berbagai hambatan administrasi maupun berbagai hambatan dalam pelaskanaannya dilapangan atau teknisnya. Di Lembaga Pemasyarakatan Klas 1 Makassar proses pemenuhan hak mendapatkan makanan yang layak bagi warga binaan pemasyarakatan banyak menghadapi kendala.

Beberapa kendala yang dihadapi dalam proses pemenuhan hak mendapatkan makanan yang layak bagi warga binaan pemasyarakatan adalah anggaran yang rendah serta kurangnya jumlah pegawai di Lembaga Pemasyarakatan Klas 1 Makassar. Anggaran yang rendah ini berdampak pada tidak terpenuhinya sarana dan prasarana yang memadai di dapur 
Lembaga Pemasyarakatan Klas 1 Makassar. Ada beberapa peralatan dapur yang menurut pegawai lembaga pemasyaraktan itu sendiri bahwa peralatan tersebut sudah dipakai berpuluh-puluh tahun dan tidak pernah diganti.

Hal tersebut berdampak pada penyediaan makanan bagi warga binaan pemasyaraktan secara kualitasnya kurang baik karena peralatan dapur yang digunakan sudah usang dan seharusnya sudah diganti dengan peralatan yang lebih baik. Hal ini tentu saja berdampak pula pada tidak terpenuhinya kecukupan gizi warga binaan pemasyarakatan selama menjalani pidana hilang kemerdekaan untuk sementara waktu di Lembaga Pemasyarakatan.

Jumlah pegawai Lembaga Pemasyarakatan Klas 1 Makassar yang kurang khususnya di bagian juru masak dan ahli gizi seharusnya diadakan perekrutan pegawai. Sehingga makanan yang disajikan secara kualitas bisa lebih baik dibandingkan dengan warga binaan pemasyarakatan sendiri yang memasak. Karena banyak warga binaan pemasyarakatan yang lain mengeluhkan bahwa makanan yang dimasak oleh rekannya sendiri sesama warga binaan pemasyarakatan kurang enak, kebersihan makanannya pun kurang terjamin serta nilai gizi dari makanan yang disajikan sangat mereka ragukan. Kemudian tidak tersediannya ahli gizi yang dapat menilai langsung makanan yang disajikan sudah bergizi atau belum karna tentu saja setiap makanan harus ditakar jumlah gizinya sebelum disajikan ke warga binaan pemasyarakatan berdasarkan Surat Edaran Keputusan Menteri Hukum dan HAM Nomor M.HH-01.PK.07.02 Tahun 2009 tentang Pedoman Penyelenggaraan Makanan Bagi Warga Binaan Pemasyarakatan di Lembaga Pemasyarakatan dan Rumah Tahanan Negara (Rutan) dengan 2250 kalori.

Over kapasitas menjadi sebuah permasalahan yang dihadapi oleh lembaga pemasyarakatan dibeberapa Negara di dunia. Kondisi over kapasitas juga dialami di lembaga pemasyarakatan di Indonesia. Tingkat kepadatan hunian LAPAS/Rutan sangat berpengaruh terhadap pelaksanaan tugas dalam hal ini pelayanan kesehatan maupun makanan bagi warga binaan pemasyarakatan. Selain berpengaruh dalam pelaksanaan tugas kondisi lapas yang over kapasitas juga berpengaruh terhadap pengawasan dan keamanan. Hal ini terjadi karena bertambahnya jumlah penghuni LAPAS/Rutan, menuntut adanya peningkatan kebutuhan dan kualitas pengawasan.

$$
\text { Keadaan Lembaga }
$$

Pemasyarakatan yang melebihi kapasitas menyebabkan pemenuhan hak-hak bagi narapidana tidak optimal. Upaya yang dapat ditempuh untuk mengatasi atau mengurangi masalh over kapasitas ini yaitu dengan memberikan hukuman pengganti dan pidana bersyarat. Hukuman pengganti dan pidana bersyarat dimaksudkan untuk mengurangi tingginya angka penjatuhan pidana terhadap pelaku tindak pidana.

\section{PENUTUP}

\section{Kesimpulan}

Berdasarkan hasil penelitian dalam penulisan skripsi ini, maka dapat disimpulkan bahwa : (1) Implementasi pemenuhan hak mendapatkan makanan yang layak bagi narapidana di Lembaga Pemasyarakatan bahwa warga binaan pemasyarakatan banyak mengeluhkan makanan yang mereka konsumsi kurang enak dengan berbagai alasan diantaranya kebersihan makanan yang kurang diperhatikan, penyedap rasa yang kurang serta gizi makanan yang kurang seimbang. Kemudian dalam proses pelaksanaan pemenuhan hak mendapatkan makanan yang layak bagi narapidana banyak yang tidak sesuai dengan prosedur dari Surat Keputusan Menteri Hukum dan HAM Nomor M.HH-01.PK.07.02 Tahun 2009 tentang Pedoman Penyelenggaraan Makanan Bagi Warga Binaan 
Pemasyarakatan di Lembaga Pemasyarakatan dan Rumah Tahanan Negara (Rutan). Sehingga implementasi pemenuhan hak mendapatkan makanan yang layak bagi narapidana berdasarkan Undang-Undang Nomor 12 Tahun 1995 tentang Pemasyarakatan belum terlaksana dengan baik. (2) Kendala yang dihadapi dalam pemenuhan hak mendapatkan makanan yang layak. Kendala yang dihadapi tidak terlaksana dengan baiknya pemenuhan hak mendapatkan makanan yang layak bagi narapidana Lembaga Pemasyarakatan Klas 1 Makassar diantaranya anggaran yang rendah sehingga berdampak pada fasilitas sarana dan prasarana yang kurang memadai. Tidak tersedianya juru masak ahli di Lembaga Pemasyarakatan dan ahli gizi yang dapat menilai langsung makanan yang disajikan sudah bergizi atau belum, sehingga berdampak pada kualitas makanan yang buruk dan gizi makanan yang tidak seimbang. Kemudian daya tampung lembaga pemasyarakatan yang tidak seimbang dengan jumlah warga binaan pemasyarakatan yang terus bertambah (over kapasitas) yang mengakibatkan pelaksanaan pemenuhan hak mendapatkan makanan yang layak belum maksimal.

\section{Saran}

Setelah melakukan analisa dari permasalahan yang ada maka penulis menyarankan : (1) Agar terlaksana dengan baik implementasi pemenuhan hak mendapatkan makanan yang layak bagi narapidan di Lembaga Pemasyarakatan Klas 1 Makassar pihak Lembaga Pemasyarakatan harus lebih bertanggungjawab, memperhatikan dan mengawasi dengan baik semua proses penyediaan makanan bagi warga binaan pemasyarakatan mulai dari makanan diterima dari pemborong sampai pada tahap disajikan untuk warga binaan pemasyarakatan. (2) Agar terlaksana dengan baiknya implementasi pemenuhan hak mendapatkan makanan yang layak pemerintah seharusnya memberikan perhatian lebih kepada narapidana sehingga hak mereka dapat diperoleh sesuai dengan peraturan perundangundangan yang ada, khususnya dalam hal mendapatkan makanan yang layak dikonsumsi di dalam Lembaga Pemasyarakatan dengan menyediakan anggaran khusus atau lebih untuk pengadaan fasilitas dapur di Lembaga Pemasyarakatan Klas 1 Makassar. Kemudian untuk pihak Lembaga Pemasyarakatan seharusnya melakukan penambahan jumlah pegawai di Lembaga Pemasyarakatan pada bagian penyediaan makanan serta melakukan perencanaan anggaran untuk penyelenggaraan penyediaan peralatan dapur yang lebih memadai dan seharusnya pihak Lembaga Pemasyarakatan memperhatikan dan melaksanakan dengan baik semua prosedur yang ada yang merupakan tanggungjawab atas tugas yang diberikan. Kemudian untuk mengatasi atau mengurangi over kapasitas bisa dilakukan dengan cara mengadakan alternatif terhadap penjatuhan pidana misalnya dengan pidana denda dan pidana kerja sosial.

\section{DAFTAR PUSTAKA}

Arief Nawawi. 2011. Kebijakan Hukum Pidana. Semarang: Kencana, Cetakan Kedua

Ari Yuniastuti. 2008. Gizi Dan Kesehatan. Yogyakarta: Graha Ilmu

Budi Winarno. 2002. Teori dan Proses Kebijakan publik. Yokyakarta: Media Pressindo

Cristian dan Direktorat Jenderal Pemasyarakan. Buku I. kantor Jakarta

Dwijadya Priyatno. 2006. Sistem Pelaksanaan Pidana Penjara di Indonesia. Bandung: PT. Reflika Aditama 
Darwan, Prinst. 1997. Hukum Anak Indonesia. Bandung: PT. Citra Aditya Bakti

Departemen Kesehatan. 2009. Pedoman Penyelenggaran Makanan di Lembaga Pemasyarakatan, Jakarta: Departemen Kesehatan RI Jenderal Bina Kesehatan Masyarakat Direktorat Bina Gizi Masyarakat.

Departemen Kesehatan. 1995. Jakarta: Depatemen Kesehatan RI D itjen Pembinaan Kesehatan Masyarakat Direktorat Bina Gizi Masyarakat.

Gunawan. 1993. Hak-Hak Asasi Manusia Berdasarkan Ideologi Pancasila. Yogyakarta: PT. Kanisiu

Moeljatno. 1993. Azaz-Azaz Hukum Pidana. Yogyakarta: Bina Aksara

Mulyana Kusumah. 1981. Analisa Kriminologi tentang Kejahatan Kekerasan. Jakarta: Halia Indonesia

Mardalis. 2014. Metode Penelitian. Jakarta: Bumi Aksara

Nananng Martono. 2011. Metode Penelitian Kuantitatif. Jakarta: Rajawali Pers

Purwadarminta. 1988. Kamus Besar Bahasa Indonesia. Jakarta: Balai Pustaka

Romli Atmasasmita. 1975. Dari pemenjaraan ke pembinaan narapidana. Bandung: Alumni

Sri Widayanti. 1983. Anak dan Wanita Dalam Hukum. Jakarta: LP3ES

Sugiyono. 2012. Metode Penelitian Kuantitatif Kualitatif. Bandung: Alfabeta

Sumardi Suryabrata. 2014. Metodologi Penelitian. Jakarta: Rajawali Pers

Sudikno Mertukusumo. 2006. Mengenal Hukum . Yogyakarta: Liberty

Sudaryo Natangga. 2005. Buku Pegangan Kuliah Hukum Pidana. Fakultas Hukum
Universitas Muhammadiyah: Surakarta

Solihin Abdul Wahab. 2008. Analisis Kebijaksanaan : dari formulasi ke implementasi kebijaksanaan Negara. Jakarta: Bumi Aksara

Tina Asmarawati. 2015. Pidana Dan Pemidanaan Dalam Sistem Hukum Di Indonesia. Yogyakarta: Deepublish Cetakan Kedua

Yuyun Astuti. 2011. Implementasi Pemenuhan Hak Atas Pelayanan Perawatan Terhadap Narapidana di Lembaga Pemasyarakatan Klas I Makassar.

Yeni Handayani. 2012. Pemenuhan Hak Atas Kesehatan Narapidana Wainta di Lembaga Pemasyarakatan Wanita Klas IIA Tangerang Periode Tahun 2011.

KEMENKES RI No. 942/MENKES/SK/VII2003

Tentang Pedoman Persyaratan Hygieni dan Sanitasi Makanan Jajanan

Peraturan Pemerintah Nomor 28 Tahun 2006 Tentang Syarat Dan Tata Cara Pelaksanaan Hak Binaan Warga Pemasyarakatan

Peraturan Menteri No. M.HH-01.PK07.02 Tahun 2009 Tentang Pedoman Penyelenggaraan Makanan Bagi Warga Binaan Pemasyarakatan di Lembaga Pemasyarakatan dan Rumah Tahanan Negara.

Undang Nomor 12 Tahun 1995 Tentang Pemasyarakatan 